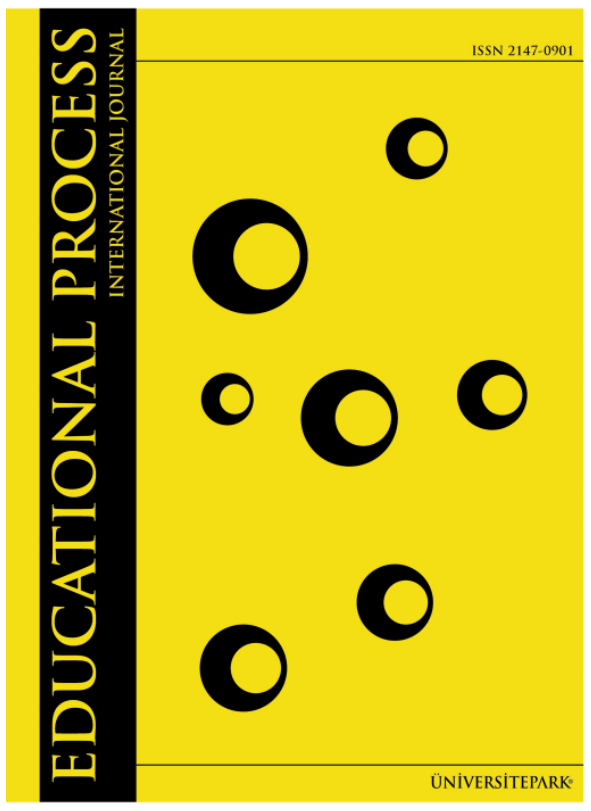

\title{
Educational Process: International Journal
}

\section{EDUCATIONAL PROCESS: INTERNATIONAL JOURNAL EDUPIJ / VOLUME 5 / ISSUE 2 / SUMMER / 2016}

Human Values and Compassionate Love in Highly Gifted Students and Normal Student

\section{Adnan Ozbey and Hakan Saricam}

To cite this article: Ozbey, A., \& Saricam, H. (2016). Human Values and Compassionate Love in Highly Gifted Students and Normal Student. Educational Process: International Journal, 5(2), 116-127.

To link to this article: $\underline{h t t p: / / d x . d o i . o r g / 10.12973 / e d u p i j .2016 .52 .3 ~}$

Adnan Ozbey, Dumlupinar University, Turkey. (e-mail: adnanozbey@ hotmail.com)

Hakan Saricam, Dumlupinar University, Turkey. (e-mail: hakan.saricam@dpu.edu.tr) 


\title{
Human Values and Compassionate Love in Highly Gifted Students and Normal Student
}

\author{
ADNAN OZBEY and HAKAN SARICAM
}

\begin{abstract}
The principal objective of this study is to examine the relationship between human values and compassionate love of highly gifted students, and to make a comparison of the levels of compassionate love and human values between highly gifted students and their normal peers. One of the quantitative models, associative patterns, were implemented in this research. These are the models used for the determining of levels and the existence of change between two or more variables. With ease of accessibility, 8th grade normal students $(\mathrm{N}=200)$ from Balıkesir and Manisa (Turkey) and highly gifted students $(\mathrm{N}=200)$ of BILSEM were selected to gather data. 102 of the normal students were female, while 98 were male. 108 of the highly gifted students were female and 92 of them male. In this research, the Human Values Scale and Compassionate Love Scale were applied in order to determine levels of human values and compassionate love of the students. In conclusion, the highly gifted students were observed to have higher levels of human values than their normal peers, and to be more sensitive regarding love.
\end{abstract}

Keywords: human values, compassionate love, gifted/talented, student.

Crossef DOI: 10.12973/edupij.2016.52.3

EDUPIJ / ISSN 2147-0901 (C 2016

Copyright (C) 2016 by ÜNIVERSITEPARK Limited

edupij.com 


\section{Introduction}

Since the first man, humans have been struggling to meet their needs by fulfilling several requirements of survival like all other creatures. Essential living conditions for survival, especially those physical and biological, are the most dominant and challenging. These conditions are the same for all living creatures, but there are other compulsory circumstances for mankind and other challenging conditions associated with the very existence of the man on earth. In other words, man who was created as the most dignified and most noble on earth, has other striking features that distinguish them from other creatures. These features, peculiar only to man, are the values we see (Saricam, Celik, Arıcı, \& Kaya, 2014). According to Dilmac, Kulaksizoglu, and Eksi (2007), human values are sublevel values known as "Responsibility", "Friendship", "Reconciliation”, "Respect", "Honesty", and "Tolerance". According to Sprecher and Fehr (2005), love is the essence of being human and thanks to this; emotions, feelings, and thereby human values foster and prosper.

Values have always been a central concept for social sciences. According to Durkheim and Weber, the values, play a vital descriptive role in social/personal changes (As quoted by Giddens, 2014; Morrison, 2006). This is an effective concept to identify groups, communities and individuals, and to keep track of actual cultural change in time, attitudes, and behaviors of instinctive foundation values (Schwartz, 2012). The values are general policies and the individual's beliefs that guide their behaviors. The values are the criteria that allow us to judge our actions; whether they are good and correct, or not (Halstead \& Taylor, 2000). While new generations are trained to receive knowledge, skills, and to prepare for professional life, at the same time the "qualities of good people" are bestowed. Jointly shared values are the requisite element for society to understand each other, to create a national consciousness, and to establish basic rudimentary elements and to provide empathy (Sener, 2013).

As a human being equipped with emotions of compassion, we can be delighted seeing joy in some, while feeling sad for the lamentations of others; such as beneficiary and charity based on conscience and behavior in surpassing justice and values bestowed or inspired. These are called human values (Dereli \& Aypay, 2012). Human beings reflect their personalities through behaviors and statements. These actions depend on and are led by human beings' minds and senses. Human behaviors shaped by minds and senses are the very basis of individual and social relations. In this way, the majority of positive results of centuries-long experience of individuals and societies and norms are accepted as behaviors, and all these have been distilled as "human values" (Dilmac, 2007).

Sensitivity is a feeling of pity to approach others and the emotional responses that require some form of intervention (Goetz, Keltner, \& Simon-Thomas, 2010). It provides peace of mind and requires complexity of the mind. It is considered as a power, protecting people from emotional devastation. While awareness supports human love and compassion that contain individuals' own thoughts, happiness and welfare, it also prevents evil emotions in the mind, including jealousy (Makransky, 2012; Sobocko \& Zelenski, 2015). Sensitivity helps an individual to make others happy who are in need, and strengthens ties of close relationships and with strangers. It also makes it easy for an individual to strengthen bonds of love with the community and to work for the well-being of the people. 
According to Fromm (2006), love is a unity in which man preserves his integrity and individuality. Love helps man rescue himself from a sense of separation and loneliness, and still allows himself to maintain his integrity. In Maslow's hierarchy of needs, love is located in the third step, immediately after the need for belonging, being accepted, trust and other physiological requirements. According to Maslow, man, as a social entity, wants to love, and wants to be loved.

Love and sensitivity, which distinguish man from other living creatures, are qualities which are the properties of virtuous people with dignity. At the same time, they are the essence of ethical values, a criterion for correct behavior and speech. Another type of love is compassionate love, which includes these concepts presented to all mankind (Bodhi, 2005; Neff \& Karney, 2005).

Compassionate love is described as sensitivity, and as a collection of thoughts emotions and behaviors directed against relatives, strangers and humanity itself; and the understanding of people when they need help, supporting them intimately, and paying close attention to the sufferings of others (Sprecher \& Fehr, 2005). Compassionate love is the type of love that makes important contributions, sacrificing of the self for the sake of others, to increasing the quality of life of an individual, and building harmony between cultures and beliefs in society (Underwood, 2008).

Compassionate love is not synonymous with concepts such as empathy, forgiveness, interest, altruism, and social support (Brody, Wright, Aron, \& McLaughlin-Volpe, 2009; Saunders, 2013). Although there are common aspects of these concepts, they don't possess the richness and depth of the compassionate concept of love (Fehr \& Sprecher, 2009), as compassionate love has a more comprehensive meaning that includes family, friends, environment and all people. Compassionate love is the kind of love that requires selfsacrifice and covers all people and has longevity (Sprecher \& Fehr, 2005). Due to these qualities, compassionate love has been called by some experts as 'unconditional love', 'love ' and ' devoted love ' (Post, Underwood, Schloss, \& Hurlbut, 2002).

Compassionate love is based on neither romantic love, nor familiar love, or friendship love. It is a type of love from which many religions consider that good and proper behaviors stem; given freely and consciously. It is not a case of something instinctive or something compulsory, so there is no expectation of receiving something in return; even it requires the individual to make sacrifices for others (Underwood, 2002, 2008).

Throughout history, many people have left deep impressions on others, playing an important role in the development of culture, civilization, and society, having lived their lives with unforgettably original features and productivity left behind. These people, through political and social leadership, superior brain power, moral virtue, faith and intuition, inventions, science contributions, and with the ability to influence and persuade others in their environment, have shaped history throughout almost every period. These are highly gifted individuals in the fields of science, art, philosophy, religion, politics, and military achievements, many of whom are still remembered by name, even today (Silverman, 1994).

The gifted, with a sharp sense of wonder, memory power, authenticity, and a sense of learning, are known to have learning differences in terms of quantity and speed, showing significant differences when compared to their peers (Cakir \& Kocabas, 2016; Webb, Gore, Amend, \& DeVries, 2007). Gifted children, with many features such as moral, physical, 
emotional, social, intellectual, or artistic talents, have the potential, as considered by experts, to be the 'standard' in their fields, and a capacity to yield productions (Tannenbaum, 2003). Moral sensitivity, one of these potentials, is of considerable importance, both for the gifted and for humanity in general.

It is an important quality of gifted students to have developed sensitivity to moral values. Gifted students pay great attention to the problems of the world and feel very concerned about feelings of the others and besides these they are unusually compassionate (Silverman, 1994). That is why gifted students perceive and review the moral aspects of situations and events they witness in their daily lives quicker than their peers, and demonstrate an exceptional attitude compared to expectations. Gifted students show moral sensitivity from an early age. It is observed that these children value other people and try to relieve their sufferings while they are oversensitive about abstract concepts such as justice and equity (Lovecky, 1997). In the works of Gross (1993), in which he undertook research with children with an IQ of 160, he stated that gifted children have a higher sense of justice, more feelings of responsibility towards others, and more self-responsibility when compared to their peers. Another researcher, Dabrowski (1994), stated that gifted students have considerably evolved in justice, honesty, and responsibility, and also that gifted students are reported to correct the wrongdoings of adults in the world (Lovecky, 1997).

An important point to take into consideration is that while the social features of the gifted are within the sphere of their capacity, a substantial part of these cutting-edge social features of gifted children can only fully evolve when they are provided with proper social opportunities and social circles. Without these facilities, social and affective aspects are not possible to develop as a whole. Giftedness is a requirement for the development of social skills; however, the environment and conditions must be suitable for the emergence of outstanding talent. Therefore, it is extremely important to diagnose gifted children as early as possible. Those diagnosed as gifted must be guided by parents and teachers for their development and the required orientation of professions and their life ahead. Otherwise, the outstanding ability of the gifted cannot be expected to take direction and develop by itself (Webb et al., 2007).

Gokdere and Cepni (2003) found that, to a great extent, education policies for gifted children conform to the basic principles of constructive approach. For this reason, education of gifted children value must be based on constructive approach for effectiveness and permanence of the gains. This work is meant to find what human values the gifted have when they are deprived of the necessary guidance, and also, which values will deteriorate, and to what extent, when they are not nurtured for development with the correct orientation.

Research findings are expected to be useful and permanent, and for the gifted to retain the values they have gained, while preparing values education program. Developing aspect of the social consciousness of the gifted students (Freeman, 2008), the sensitivity they have for the environment and humanity, the extent of compassionate love for living things they feel and social harmony (Parker, 1996; Neihart, 1999) adaptation to the difficulties they encounter - all these issues are the focal points to be determined here. Recognition and education of gifted students are thought to contribute to the teaching of values in particular, and also to help social harmonization. Finally, when both domestic as well as foreign 
literature was searched, such a study on gifted students seems not to have been published. This work will aim to shed some light on these shortcomings.

The main objective of this study is to evaluate the relations between human values and compassionate love of gifted students. The purpose of the study is to compare the levels of compassionate love and human values between gifted children and their normal peers. Along this point, the following hypotheses have been argued.

- Gifted students will have statistically higher scores of human values than normal students.

- Gifted students will have statistically higher scores of compassionate love than normal students.

- There will be a positive relationship between human values and compassionate love in gifted students.

\section{Methodology}

In the research, of the quantitative methods the relational survey model was implemented; associative browsing models are those research models which focus to determine the existence and degree of change between two and more numerous variables (Punch, 2009, 2013). In this research, the relationship between human values and compassionate love was studied to find out the correlation.

With easy accessibility sampling, normal 8th grade students selected from secondary schools in Manisa and Balıkesir and also another gifted students of BILSEM were used to help us in our research to obtain data. Of the normal students, 102 were female and 98 of them male, whereas 108 of the gifted students were female and 92 of them male.

\section{Data collection tools}

The Human Values Scale: In this study, the Human Values Scale, as developed by Dilmac et al. (2007) for high school-level students (teenagers) (or HVS), has been used to identify the human values of the students. In this scale are the human values of: A) Responsibility (7 items); B) Friendship (7 items); C) Reconciliation (7 items); D) Respect (7 items); E) Tolerance ( 7 items); F) Honesty ( 7 items). In total, 42 items are measured within six subscales. This scale can be applied individually or in groups as a Likert-type scale. A five-point Likert-type (1: Never, 2: Rarely, 3: Sometimes, 4: Often, 5: Always) grading scale has been used for the items on the scale. Choices are scored as the following $A: 1, B: 2, C: 3, D: 4$, and $E: 5$. Increasing or decreasing in points shows that individuals have more, or less, human values. For the reliability of HVS, the internal consistency coefficients (Cronbach Alpha) were calculated. Internal consistency coefficient was calculated as $\alpha=.73$ for the "responsibility sub-scale"; $\alpha=.69$ for the friendship sub-scale, $\alpha=.65$ for the reconciliation sub-scale, $\alpha=.67$ for the respect sub-scale, $\alpha=.69$ for the honesty sub-scale, $\alpha=.70$ for the tolerance subscale, and $\alpha=.92$ for the whole scale. The determination coefficients were measured as .73 for "Responsibility", .91 for "Friendship" .80 for "Reconciliation", .88 for "Respect", .75 for "Honesty", and .79 for "Tolerance". The coefficient of determination for the whole scale is .87. In this study, the Cronbach Alpha coefficient of internal consistency reliability is .64 for responsibility, .64 for friendship, .64 for reconciliation, .68 for respect, .60 for honesty; .61 for tolerance, and for the whole scale it was measured as .84 . 
Compassionate Love Scale: The 21 item scale was translated and adapted by Akin and Eker (2012). Items include, for example, "I often have sensitivity to feelings against the people in need" and "When I see people I don't know upset, I feel an urge to lend a hand to them". Items are seven-level Likert-types, ranging from (1) "For me it's not true at all", to (7) "For me, it's totally true". For structural validity, DFA was applied for verification of factors found in the original form of the scale. The value of the Ki-square applied in DFA measured as the following $\left(\chi^{2}=577.16, N=356, d f=181, p=0.0000\right)$ and this measurement is a meaningful value. Fit index values read as $\mathrm{RMSEA}=.079, \mathrm{NFI}=.94, \mathrm{CFI}=.96, \mathrm{RFI}=.93$, and $\mathrm{SRMR}=.063$. Index values show that the one-dimensional compassionate love model works well in terms of adaptability. Items with factor loadings of the items are listed to range from .41 to .78. For the reliability analysis of the Compassionate Love Scale, internal consistency was checked, and the Cronbach's coefficient $\alpha$ reliability scale was .89. Correlation tests of the scale were observed to have ranked between .28 and .70 for the items. In this study, the Cronbach Alpha coefficient of internal consistency reliability was .94.

Preceding the official correspondence with both state schools and BILSEM schools, the schools and institutions were visited during hours assigned to us by the principals. The objective of the current study was explained to students before implementing the applications, and at the end, some gifts were given. After a period of 35 minutes, the application forms were collected and the data was transferred to a computer. Independent t-test was applied to the data with the normal distribution in order to detect differences between variables, and correlation analysis was used to determine relationships between variables.

\section{Findings}

\section{Comparison analysis}

Independent samples $t$ test was applied to compare human values and compassionate love levels of the gifted children with the levels of human values and compassionate love of their normal peers, and the results are shown in Table 1.

Table 1. Comparison of human values and compassionate love levels for students

\begin{tabular}{lcccccc}
\hline & Student & $\mathrm{N}$ & Mean & $\mathrm{SD}$ & $\mathrm{t}$ & $\mathrm{p}$ \\
\hline Responsibility & Normal & 200 & 27.07 & 4.05469 & \multirow{2}{*}{. } & \\
& Gifted & 200 & 29.11 & 3.69530 & 3.14 & $.00^{* *}$ \\
Friendship & Normal & 200 & 28.15 & 4.03009 & & \\
& Gifted & 200 & 29.29 & 3.78549 & 1.87 & .06 \\
Reconciliation & Normal & 200 & 26.30 & 4.76481 & & \\
& Gifted & 200 & 27.60 & 3.92857 & 2.46 & $.03^{*}$ \\
Respect & Normal & 200 & 27.69 & 4.77794 & & \\
& Gifted & 200 & 29.02 & 4.09892 & & $.00^{* *}$ \\
Honesty & Normal & 200 & 26.18 & 3.47973 & 3.28 & $.00^{* *}$ \\
& Gifted & 200 & 28.89 & 2.86599 & & \\
Tolerance & Normal & 200 & 21.60 & 3.53736 & 3.76 & $.00^{* *}$ \\
& Gifted & 200 & 23.06 & 3.37598 & & \\
\hline
\end{tabular}




\begin{tabular}{lccrccc}
\hline & Student & $\mathrm{N}$ & Mean & SD & $\mathrm{t}$ & $\mathrm{p}$ \\
\hline Human Values & Normal & 200 & 156.99 & 16.91715 & \multirow{2}{*}{7.52} & $.00^{* *}$ \\
& Gifted & 200 & 166.97 & 14.72538 & & \\
Compassionate & Normal & 200 & 94.65 & 23.45292 & & \\
love & Gifted & 200 & 106.87 & 23.95633 & & $.00^{* *}$ \\
\hline
\end{tabular}

${ }^{* *} p<.01,{ }^{*} p<.05$

When Table 1 is studied, human values in gifted children had an average score of $\bar{X}$ $=166.97$ and the average score of normal children's human values is $\bar{X}=156.99$. This difference is statistically $p<.05$ and the importance level is meaningful $(t=7.52 ; p<.05)$. Gifted children's sensitive love level ( $\bar{X}=106.87$ ) is statistically more than the normal children ( $\bar{X}$ $=94.65)$ and is significant $(t=4.48 ; p<.05)$. These differences apply to the lower dimensions of responsibility $(t=3.14 ; p<.05)$, reconciliation $(t=2.46 ; p<.05)$, respect $(t=3.08 ; p<.05)$, honesty $(t=3.28 ; p<.05)$, and tolerance $(t=3.76 ; p<.05)$. On the other hand, average points of the gifted children's friendship ( $\bar{X}=166.97$ ) is more than the average of the normal children ( $\bar{X}$ $=156.99$ ), but these differences are statistically meaningless ( $t=1.87 ; p>.05)$.

\section{Correlation findings}

The Pearson moment correlation analysis was applied to the gifted children to ascertain whether or not there is a relationship between human values and compassionate love and the results are shown in Table 2.

Table 2. Results of correlation analysis concerning relationship between gifted children's human values and compassionate love.

\begin{tabular}{lcccccccc}
\hline Variables & 1 & 2 & 3 & 4 & 5 & 6 & 7 & 8 \\
\hline 1. Responsibility & - & & & & & & & \\
2. Friendship & $.42^{* *}$ & - & & & & & & \\
3. Reconciliation & $.55^{* *}$ & $.31^{* *}$ & - & & & & & \\
4. Respect & $.65^{* *}$ & $.46^{* *}$ & $.52^{* *}$ & - & & & & \\
5. Honesty & $.40^{* *}$ & $.26^{* *}$ & $.26^{* *}$ & $.40^{* *}$ & - & & & \\
6. Tolerance & $.25^{*}$ & $.26^{*}$ & $.28^{*}$ & $.25^{*}$ & $.32^{*}$ & - & & \\
7 Human values & $.78^{* *}$ & $.63^{* *}$ & $.76^{* *}$ & $.80^{* *}$ & $.65^{* *}$ & $.55^{* *}$ & - & \\
8. Compassionate & $.38^{* *}$ & $.39^{* *}$ & $.40^{* *}$ & $.44^{* *}$ & $.33^{* *}$ & $.46^{* *}$ & $.51^{* *}$ & - \\
love & 29.11 & 29.29 & 27.60 & 29.02 & 28.89 & 23.06 & 166.97 & 106.87 \\
$\bar{X}$ & 3.69 & 3.78 & 3.93 & 4.10 & 2.87 & 3.38 & 14.72 & 23.96 \\
SD & & & & & & &
\end{tabular}

$* * p<.01, * p<.05$

As shown in Table 2, There is a positive relationship between compassionate love and human values of the gifted students in terms of level of importance as the measurements indicate like $r .=51$ and $p<01$. In other words, as compassionate love increases, so do the human values. It is possible to say the same thing for the relationship between the lower cases of compassionate love and human values. In addition, human values have positive relationships between the lower cases. 


\section{Conclusion and Discussion}

The main objective of this research was to determine the relationship between human values and compassionate love. For this purpose, three sub-hypotheses were formed. In the first hypothesis, gifted students were expected to score higher human values. As a result of the study, the human values score of the gifted students proved to be statistically higher than those of the normal students. According to the results of the numerous studies applied on the gifted, we reached the conclusion that gifted children fit more comfortably, socially and emotionally to the environment (Clark, 2002; Gross, 2002; Robinson \& Noble, 1991; Sampson, 2013). As they rapidly grasp social values of the environment they live in, they are extremely successful in adaptation (Saricam \& Sahin, 2015). They mature in interaction with the outside world (Webb et al., 2007). Ozbey and Saricam (2015) stated that gifted children have tolerant, compassionate, and constructive attitudes towards their environment. Cetinkaya and Kincal (2015) cited that research in the field of education of democracy for gifted student's shows that they have a significant influence in the increase of love, awareness and tolerance. Topcu (2015) observed that in the study of perception of gifted students' value concept, they generally have positive attitudes about the concept of perspectives and values. Research proved that qualities giving priority to the lives of gifted students were values such as honesty, respect, tolerance, trust, love, being a good human, understanding, and not telling lies. In their work on gifted children's character traits and values education study, Freeman (2008) stated that they gave priority to the values and had high levels of moral values (Hosgorur \& Gecer, 2012; Nelson, 1981). In conclusion of their study into the value orientations and education of gifted children, it was stated that they also have higher religious, spiritual potential, and moral potential interests.

In the second hypothesis of this current research, the gifted students have statistically higher scores of compassionate love higher than seen for normal students. As a result of this study, compassionate love points of the gifted students are statistically higher than those of the normal students. It is observed that the gifted students have high levels of sensitiveness. They experience life in an intense way (Daniels \& Meckstroth, 2009). They have high levels of compassion towards other people and at the same time they are very sensitive to people's feelings (Robinson \& Noble, 1991; Silverman, Gilman, \& Falk, 2004). Therefore, when they could not produce solutions to negative events in progress, they feel desperate and even worse; they can experience the psychology of guilt. This emotional state is often misunderstood by other people.

As a result, gifted children have more human values than their normal peers, and they are more sensitive when it comes to love. Based on this research's findings compassionate love seems to be the leading reason just because the gifted students have more human values. When gifted children are evaluated from the health perspective, both physically and morally, they outscore their peers and their test points are much higher in the fields of, moral behavior and character, and their value orientation reached to higher levels (Subotnik \& Arnold, 1994). Gifted students have empathetic and sensitive attitudes against people and also they carry high levels of compassion. At the same time they feel responsible for universal problems to an extent that they can dedicate themselves to problems of all living things (Silverman, 1994; Clark, 2008). 
When the Schwarzt's (2012) value classification is closely scanned, the readings seem to support the results of the research. Universalism value type is defined as understanding, appreciation, tolerance, good will for the benevolence of others and the conservation of nature. When the sub-values are taken into consideration, social justice and equality, a will for world peace and a world with no battle zones, protection of the environment, virtuousness, are the sub-dimensions that can be listed. These findings support the results of the research. And these being the case, the three hypothesis of the current research are verified.

There are a number of limitations to the research of the current study. First of all, when you look at the number of the items used on the scale, the study group is very small. Future studies should expand the number of sample groups. Another limitation is that the scales used in the current study were developed for adults. By renewing reliability analysis for the secondary school students, this limitation was overcome to a degree, so structural validity should be reexamined.

\section{Notes}

Corresponding author: HAKAN SARICAM

This study was presented partially in the Second National Congress on Values Education (with international participation) 5th-7th November 2015, Kirikkale, Turkey. This research was developed from the 1st authors' PhD thesis at Dumlupinar University, Institute of Educational Sciences, supervised by the 2 nd author.

\section{References}

Akin, A., \& Eker, H. (2012). Compassionate Love: A study of validity and reliability. Uludag University Journal of education Faculty, 25(1), 75-85.

Bodhi, B. (2005). In the Buddha's words: An anthology of discourses from the pali canon. Boston: Wisdom Publications.

Brody, S., Wright, S. C., Aron, A., \& McLaughlin-Volpe, T. (2009). Compassionate love for individuals in other social groups. In B. Fehr, S. Sprecher, \& L. Underwood (Eds.). The science of compassionate love: Theory, research, and applications. Malden, Mass.: Blackwell Publishing.

Cakir, L., \& Kocabas, I. (2016). Mentoring in gifted student's education and a model suggestion. Educational Process: International Journal, 5(1), 76-90.

Cetinkaya, C., \& Kincal, R. Y. (2015). Democracy education of gifted and talented children. Journal of Gifted Education Research, 3(1), 1-22.

Clark, B. (2002). Growing up gifted: Developing the potential of children at home and at school. Upper Saddle River, NJ: Merrill: Prentice Hall.

Clark, B. (2008). Growing up gifted: Developing the potential of children at home and at school (7th ed.). Upper Saddle River: Pearson.

Dabrowski, K. (1994). The heroism of sensitivity. (E. Hyzy-Strzelecka, Trans.). Advanced Development, 6, 87-92.

Daniels, S., \& Meckstroth, E. (2009). Nurturing the sensitivity, intensity, and developmental potential of gifted young children. In S. Daniels \& M. Piechowski (Eds.), Living with intensity (pp. 33-56). Scottsdale, AZ: Great Potential Press. 
Dereli, E., \& Aypay, A. (2012). The prediction of empathetic tendency and characteristic trait of collaboration on humane values in secondary education students and the examining to those characteristics. Educational Sciences: Theory \& Practice, 12(2), 1262-1270.

Dilmac, B. (2007). The assessment of the teaching of human values which are imposed a group of science high school students by human values scale. Unpublished doctoral dissertation, Selçuk University, Konya.

Dilmac, B., Kulaksızoglu, A., \& Eksi, H. (2007). An examination of the humane values education program on a group of science high school students. Educational Sciences: Theory \& Practice, 7(3), 1221-1261.

Fehr, B., \& Sprecher, S. (2009). Compassionate love: Conceptual, measurement, and relational issues. In B. Fehr, S. Sprecher, \& L. Underwood (Eds.). The science of compassionate love: Theory, research, and applications. Malden, Mass.: Blackwell Publishing.

Freeman, J. (2008). Morality and giftedness. In T. Balchin, B. Hymer, \& D. Mathews (Eds.) The Routledge international companion to gifted education (pp.141-148). London and New York: Routledge.

Fromm, E. (2006). The art of loving. NY: HarperCollins Publishers.

Gallagher, J. J. (1991). Educational reform, values, and gifted students. Gifted Child Quarterly, 35(1), 12-19.

Giddens, A. (2014). Capitalism and Modern Social Theory: An analysis of the writings of Marx, Durkheim and Max Weber $\left(19^{\text {th }}\right.$ ed.). UK: Cambridge University Press.

Goetz, J. L., Keltner, D., \& Simon-Thomas, E. (2010). Compassion: An evolutionary analysis and empirical review. Psychological Bulletin, 136(3), 351-374.

Gökdere, M., \& Çepni, S. (2003). Üstün yetenekli çocuklara verilen değerler eğitiminde öğretmenin rolü. Journal of Values Education, 1(2), 93-107.

Gross, M. U. (1993). Nurturing the talents of exceptionally gifted individuals. International handbook of research and development of giftedness and talent, 1, 473-490.

Gross, M. U. (2002). Social and emotional issues for exceptionally intellectually gifted students. In M. Neihart, S. Reis, N. Robinson, \& S. Moon (Eds.) The social and emotional development of gifted children. What do we know. (pp.19-30). Waco: Prufrock Press Inc.

Halstead, J. M., \& Taylor, M. J. (2000). The development of values, attitudes and personal qualities: A review of recent research. Slough: National Foundation for Educational Research.

Hosgorur, T., \& Gecer, A. (2012). Gifted students' views about teachers' desired characteristics. Educational Process: International Journal, 1(1-2), 39-49.

Lovecky, D. V. (1997). Identity development in gifted children: Moral sensitivity. Roeper Review, 20(2), 90-94.

Makransky, J. (2012). Compassion in Buddhist psychology. In C. K. Germer and R. D. Siegel (Eds) Wisdom and compassion in psychotherapy: Deepening mindfulness in clinical practice. (pp. 61-74). NY: Guilford Press.

Morrison, K. (2006). Marx, Durkheim, Weber, second edition: Formations of modern social thought. UK: Sage Publications. 
Neff, L. A. \& Karney, B. R. (2005). To know you is to love you: The implications of global adoration and specific accuracy for marital relationships. Journal of Personality and Social Psychology, 90, 480-497.

Neihart, M. (1999). The impact of giftedness on psychological well-being. Roeper Review, 22(1), 123-127.

Nelson, R. G. (1981). Values education for gifted adolescents. Roeper Review, 3, 10-11.

Ozbey, A., \& Saricam, H. (2015). Human values and compassionate love in gifted and nongifted students [Üstün yetenekli öğrenciler ve normal öğrencilerde insani değerler ve duyarlı sevgi]. The Second National Congress on Values Education (With International Participation), 5th-7th November, 2015, Kırıkkale, Turkey.

Parker, W. D. (1996). Psychological adjustment in mathematically gifted students. Gifted Child Quarterly, 40(3), 154-157.

Post, S. G., Underwood, L. G., Schloss, J. P., \& Hurlbut, W. B. (2002). Altruism and altruistic love: Science, philosophy, and religion in dialogue. Oxford University Press.

Punch, K. F. (2009). Introduction to research methods in education. SAGE Publications Ltd

Punch, K. F. (2013). Introduction to social research: Quantitative and qualitative approaches. SAGE Publications Ltd

Robinson, N. M., \& Noble, K. D. (1991). Social-emotional development and adjustment at gifted children. In M. C. Wang, M. C. Reynolds, \& H. J. Walberg (Eds.) Handbook of special education: Research and practice (pp. 57-76). New York: Pergamon Press.

Sampson, C. (2013). Social and emotional issues of gifted young children. APEX: The New Zealand Journal of Gifted Education, 18(1). Retrieved from www.giftedchildren.org.nz/apex

Saricam, H., Celik, I., Arıcı, N., \& Kaya, M. M. (2014). The examination of relationship between human values and moral maturity in adolescence. International Journal of Human Sciences, 11(1), 1325-1342.

Saricam, H., \& Sahin, S. H. (2015). The relationship between the environmental awareness, environmental attitude, curiosity and exploration in Highly Gifted Students: Structural Equation Modelling. Educational Process: International Journal, 4(1-2), 7-17.

Saunders, W. (2013). Love+ Compassion= Community. Growing compassionate love in Communities. YMCA of Metropolitan: Los Angeles.

Schwartz, S. H. (2012). An overview of the Schwartz theory of basic values. Online Readings in Psychology and Culture, 2(1), 11.

Sener, H. (2013). The transferred values in Hayriyye-i Nabi. Turkish Studies International Periodical for the Languages, Literature and History of Turkish or Turkic, 8(1), 25012524.

Silverman, L. K. (1994). The moral sensitivity of gifted children and the evolution of society. Roeper Review, 17(2), 110-116.

Silverman, L. K., Gilman, B., \& Falk, R. (2004). Who are the gifted using the new WISC-IV. Paper presented at the 51st annual convention of the National Association for Gifted Children, Salt Lake City, UT.

Sobocko, K., \& Zelenski, J. M. (2015). Trait sensory-processing sensitivity and subjective wellbeing: Distinctive associations for different aspects of sensitivity. Personality and Individual Differences, 83, 44-49. 
Sprecher, S., \& Fehr, B. (2005). Compassionate love for close others and humanity. Journal of Social and Personal Relationships, 22(5), 629-651.

Subotnik, R. F., \& Arnold, K. D. (1994). Beyond Terman: Contemporary longitudinal studies of giftedness and talent: Greenwood Publishing Group.

Tannenbaum, A. (2003). Nature and nurture of giftedness. Handbook of gifted education, 3, 45-59.

Topcu, S. (2015). Wunderkind students' perception according to the concept of value: Elaziğ Art and Science Center example. Turkish Studies International Periodical for the Languages, Literature and History of Turkish or Turkic, 10/11, 1449-1470.

Underwood, L. G. (2002). The human experience of compassionate love: Conceptual mapping and data from selected studies. In S. G. Post, L. G. Underwood, J. Schloss, \& W. B. Hurlbut (Eds.), Altruism and altruistic love: Science religion philosophy in dialogue (pp.72-88). Oxford University Press.

Underwood, L. G. (2008). Compassionate love: A framework for research. In B. Fehr, S. Sprecher, \& L. G. Underwood (Eds.), The science of compassionate love: Theory, research, and applications, (pp.3-25). Wiley-Blackwell.

Webb, J. T., Gore, J. L., Amend, E. R., \& DeVries, A. R. (2007). A parent's guide to gifted children (Paperback). Scottsdale, AZ: Great Potential Press. 